\title{
Hypocenter distribution of plate boundary zone off Fukushima, Japan, derived from ocean bottom seismometer data
}

\author{
Masanao Shinohara ${ }^{1}$, Ryota Hino $^{2}$, Takashi Yoshizawa ${ }^{3 *}$, Minoru Nishino $^{2}$, Toshinori Sato ${ }^{4}$, and Kiyoshi Suyehiro ${ }^{5}$ \\ ${ }^{1}$ Earthquake Research Institute, University of Tokyo, 1-1-1 Yayoi, Bunkyo-ku, Tokyo 113-0032, Japan \\ ${ }^{2}$ Research Center for Prediction of Earthquakes and Volcanic Eruptions, Graduate School of Science, Tohoku University, \\ Aoba-ku, Sendai 980-8578, Japan \\ ${ }^{3}$ Graduate School of Science and Technology, Chiba University, 1-33 Yayoi-cho, Inage-ku, Chiba 263-8522, Japan \\ ${ }^{4}$ Department of Earth Sciences, Faculty of Science, Chiba University, 1-33 Yayoi-cho, Inage-ku, Chiba 263-8522, Japan \\ ${ }^{5}$ Japan Agency for Marine-Earth Science and Technology, 2-15 Natsushima-cho, Yokosuka 237-0061, Japan
}

(Received January 27, 2004; Revised February 16, 2005; Accepted February 16, 2005)

\begin{abstract}
Microearthquake observation using Ocean Bottom Seismometers (OBSs) was carried out to obtain a detailed distribution of microearthquakes beneath the area off Fukushima, in the middle section of the Japan Trench in the summer of 1997. The observation period spanned approximately one month. Almost all of the well-determined hypocenters occurred in the vicinity of the plate boundary in this region (approximately $100 \mathrm{~km}$ landward of the trench axis), while seismicity is markedly lower between this area and the trench itself. The seaward limit of the high seismicity region is close to the western end of the zone of direct contact between the oceanic crust and the overriding landward crust. Twenty-nine earthquakes were recorded within the overriding landward plate. Twelve earthquakes were recorded about $30 \mathrm{~km}$ below the plate boundary, and form a landward dipping plane that appears to be an up-dip continuation of the lower plane of the double seismic zone. The microseismicity characteristics of the plate boundary region are interpreted to be controlled by the geometry and physical properties of the plate interface. The seismic activity in the lower seismic plane near the trench is considered to relate to bending of the subducting plate and to dehydration of serpentinized Pacific Plate mantle.
\end{abstract}

Key words: Ocean bottom seismometer (OBS), microearthquake, Japan Trench, subduction, double planed seismic zone.

\section{Introduction}

The seismicity of the northeastern Japan arc is as high as that observed in other areas of subduction of oceanic plates. The Pacific Plate is subducting beneath the northeastern Japan Arc at the Japan Trench with a convergence rate of $8.3 \mathrm{~cm} /$ year (DeMets et al., 1990, 1994). The Japan Trench area has high microearthquake seismicity and large earthquakes with magnitude greater than 7 are frequent in the historical and observational record. Most earthquakes are considered to occur around the plate boundary with focal mechanisms indicating low-angle thrust type (Umino et al., 1990; Hasegawa et al., 1994). Inside the subducting slab, deep earthquakes occur down to $670 \mathrm{~km}$ depth and the deep seismic zone extending from 60-200 km depth is interpreted to have a double-planed structure (Hasegawa et al., 1978a, 1978b). The epicentral distribution of microearthquakes estimated by the land seismic network indicates non-uniform seismic activity along the trench axis (e.g. Hino et al., 1996). The spatial variability of seismicity along the trench axis may be related to the character of

*Present address: St. Cecilia Girls' Junior and Senior High School, Minami-rinkan 3-10-1, Yamato, Kanagawa 242-0006, Japan.

Copy right(c) The Society of Geomagnetism and Earth, Planetary and Space Sciences (SGEPSS); The Seismological Society of Japan; The Volcanological Society of Japan; The Geodetic Society of Japan; The Japanese Society for Planetary Sciences; TERRAPUB seismic coupling between the Pacific plate and the overriding landward plate. In order to understand the dynamics of subduction and to explore possible controls on seismic activity in this area, it is important to investigate the precise spatial distribution of microearthquakes both near the trench and along the plate boundary at depth.

Since there are few permanent seismic stations in the trench area, it is difficult to determine the precise position of hypocenters from data recorded by land-based seismic networks. Recent studies using Ocean Bottom Seismometers (OBS) have obtained precise hypocenter locations in the trench (e.g. Hirata et al., 1983, 1985, 1989; Kasahara et al., 1982; Hino et al., 1996, 2000; Nishizawa et al., 1990a, 1990b, 1992). Low seismicity beneath the landward slope in the vicinity of the trench was observed using OBS studies. In the Japan Trench area, this low seismicity region corresponds to water depths greater than $4000 \mathrm{~m}$ on the landward side of the trench at about $40^{\circ} \mathrm{N}$ (Hirata et al., 1985). Low seismicity areas have also been reported for other subduction zones and trench segments near the Japanese islands (Hirata et al., 1989; Iwasaki et al., 1991; Yakiwara et al., 1996). In the Nankai Trough region, Obana et al. (2001) inferred from thermal modeling that the seaward boundary of the observed high seismicity zone occurs near the up-dip limit of a mechanically locked section of the plate boundary. Low seismicity zones near the trench can be explained by weak coupling between the subducting 


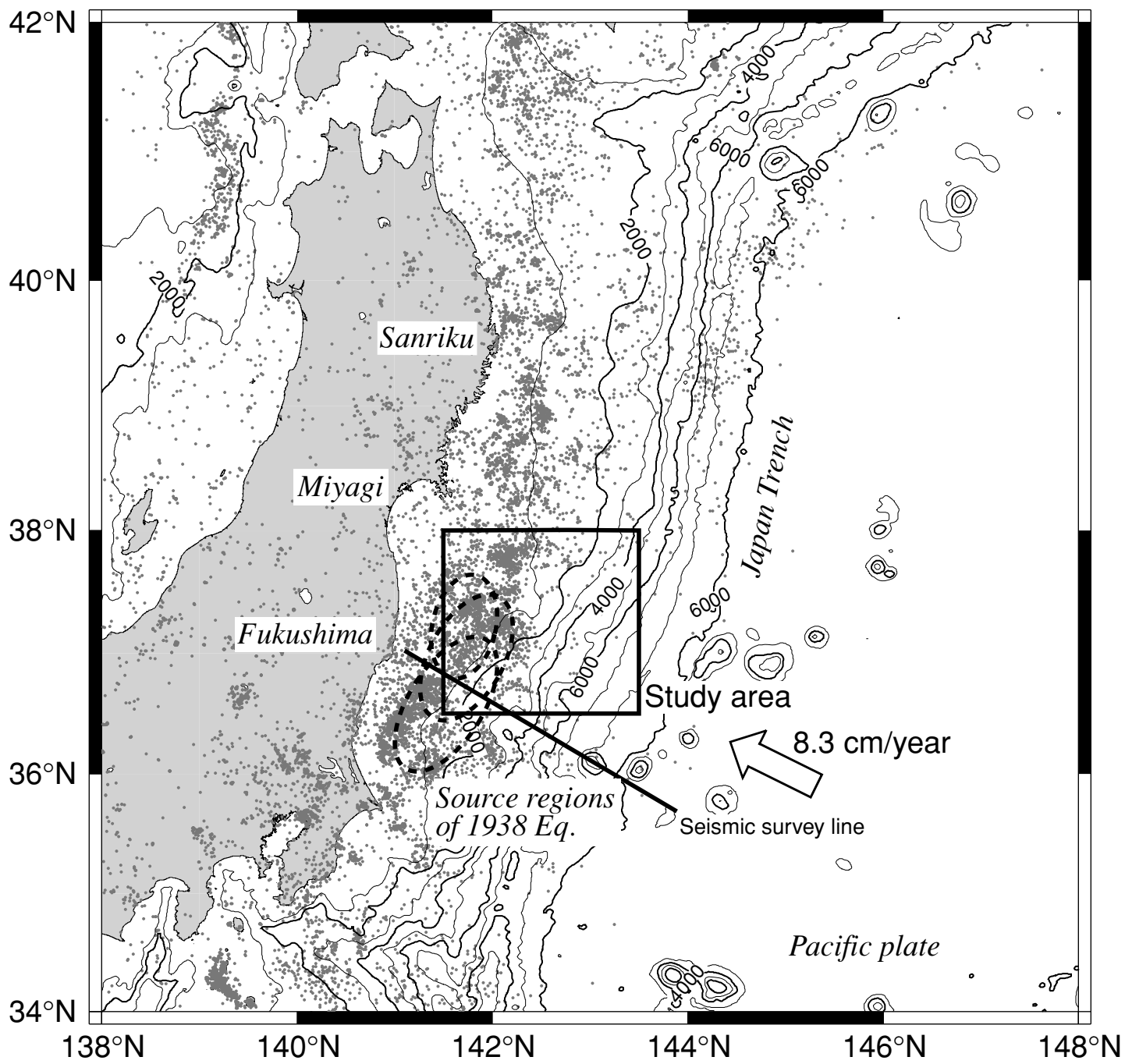

Fig. 1. Bathymetry map of the Japan Trench area. Contour interval $1000 \mathrm{~m}$. The rectangle indicates the survey area. Small gray dots denote epicenters with magnitudes of greater than 2 determined by Japan Meteorogical Agency in 2002. The Pacific plate subducts with a convergence rate of about $8 \mathrm{~cm} /$ year. Thick straight line indicates the profile of seismic velocity survey (Miura et al., 2003). Regions surrounded by dashed curves denote the source regions of the 1938 large earthquakes inferred by Abe (1977).

oceanic plate and the overriding landward plate. Suyehiro and Nishizawa (1994) suggested that the seismic coupling of interacting plates is related to the strength of the crust of the overriding landward plate and the characteristics of the subducting sediments. In the region off Sanriku, a correlation between seismic activity and seismic reflection intensity was found by a controlled-source airgun/OBS seismic experiment (Fujie et al., 2002). The observed large amplitude reflections from the plate boundary zone were interpreted as evidence for a thin, hydrated or fluid saturated low velocity layer.

The region off Fukushima lies along the middle part of the landward slope of the Japan Trench (Fig. 1). Although there are no earthquakes with a magnitude greater than 8 in the historical record in this region (Abe, 1977), the area does exhibit very high occurrence of seismic events with magnitudes ranging from less than 1 to 6 . In 1938, five earthquakes with magnitudes 7 -class occurred, consisting of a combination of low-angle thrust and nearly vertical normal-fault types (Abe, 1977). Earthquake observations in the region off Fukushima using OBSs were carried out in 1982, 1985 and 1987 (Urabe, 1987; Nishizawa et al., 1990b). These OBS studies clearly show a dipping highseismicity zone that corresponds to the plate boundary. In addition, Nishizawa et al. (1990b) reported two earthquakes at a depth of approximately $40 \mathrm{~km}$ below the plate boundary, and concluded that the deep earthquakes took place along the lower plane of the inferred double seismic zone.

To understand subduction zone dynamics, it is important to map detailed hypocenter distributions in the vicinity of the seismic front, the up-dip limit of the interplate seismogenic zone. The advantage of the new generation of digital recording OBSs (e.g. Shinohara et al., 1993) is their wide dynamic range, which enables the accurate recording of later arrivals (such as S-waves and/or converted waves), allowing high-resolution hypocentral determination. The objectives of this work are to obtain a detailed distribution of microearthquakes beneath the landward slope in the offFukushima region using OBS data and to reveal the character of the observed seismicity to understand the dynamics of 


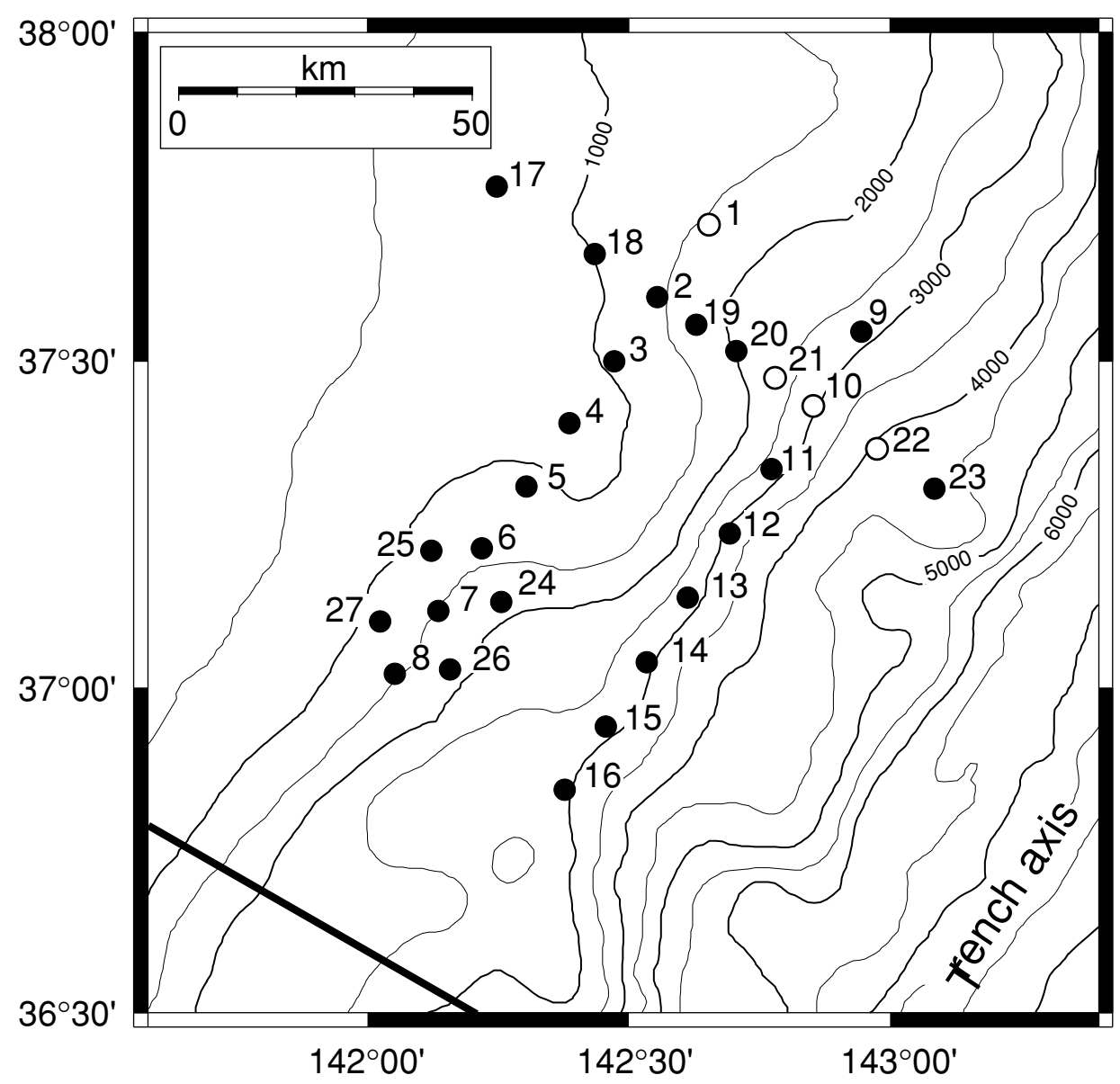

Fig. 2. Location map of ocean bottom seismometers with bathymetric features. The experiment took place off Fukushima along the landward slope of the Japan Trench. Circles denote positions of OBS. Numerals indicate OBS number. A total of 27 OBSs were deployed to carry out microearthquake observation and a seismic structure survey. Open circles show positions of OBS whose data could not be used. Thick line shows the profile of seismic refraction survey in 1998 (Miura et al., 2003).

subduction in the region off Fukushima, the Japan Trench.

\section{Observation}

Seismic observation was carried out from August to September 1997. Twenty-seven OBSs were deployed around the seismic front by four institutions: Earthquake Research Institute (University of Tokyo), Tohoku University, Ocean Research Institute (University of Tokyo), and Chiba University. The OBS array covered the landward slope of the Japan Trench from water depths ranging between $800 \mathrm{~m}$ to $4300 \mathrm{~m}$ (Fig. 2). The experiment included both earthquake observation and refraction-reflection seismic surveys using airgun sources. The seismic surveys were carried out along three survey lines designed to determine the structure of the plate boundary region: two lines are parallel to the trench and the third is perpendicular to the trench (Nishino, 1999), with the OBS array mainly deployed along these three lines. This configuration of the OBS array was also effective for resolving microearthquake hypocenters. In order to investigate detailed seismic activity in the region, OBSs were deployed in a dense array in the southwestern part of the study area (Aoyagi, 1999). The OBSs were deployed and the seismic structure surveys were performed from August 8-11, 1997. After one month of earthquake observations, the OBSs were recovered from September 9-
12, 1997. Recorded data from twenty-three OBSs were used for hypocenter determination. The ship position and water depth were determined by GPS and echo sounder, respectively.

Five types of free-fall/pop-up OBSs were used, all equipped with three-component seismometers. The ERI type has seismometers with a natural frequency of $2 \mathrm{~Hz}$ and the signals from the seismometers are converted to digital form and stored on MO (magneto-optical) disk (Kasahara et al., 1995, 1997). The Tohoku type (Shiobara et al., 1996), and the Chiba-ORI type (Shinohara et al., 1993) have seismometers with a natural frequency of $4.5 \mathrm{~Hz}$ with 16-bit resolution digital data stored on DAT tape after A/D conversion. The HD type (Mochizuki et al., 1997) is similar to the Tohoku and Chiba-ORI types, but data are stored in hard disks. The analog type (Kanazawa and Shiobara, 1994) has $4.5 \mathrm{~Hz}$ seismometers with signal recording directly onto audiotape in analog form. Due to the narrow dynamic range of this style of recording, the signals are amplified and recorded using three different gains. On shore after the recovery cruise, the records from the analog type OBSs were digitized with 16-bit resolution at a sampling frequency of $80 \mathrm{~Hz}$ (Urabe and Hirata, 1984).

Since the OBSs were deployed by free-fall, the positions of the OBSs on the sea floor were determined employing 


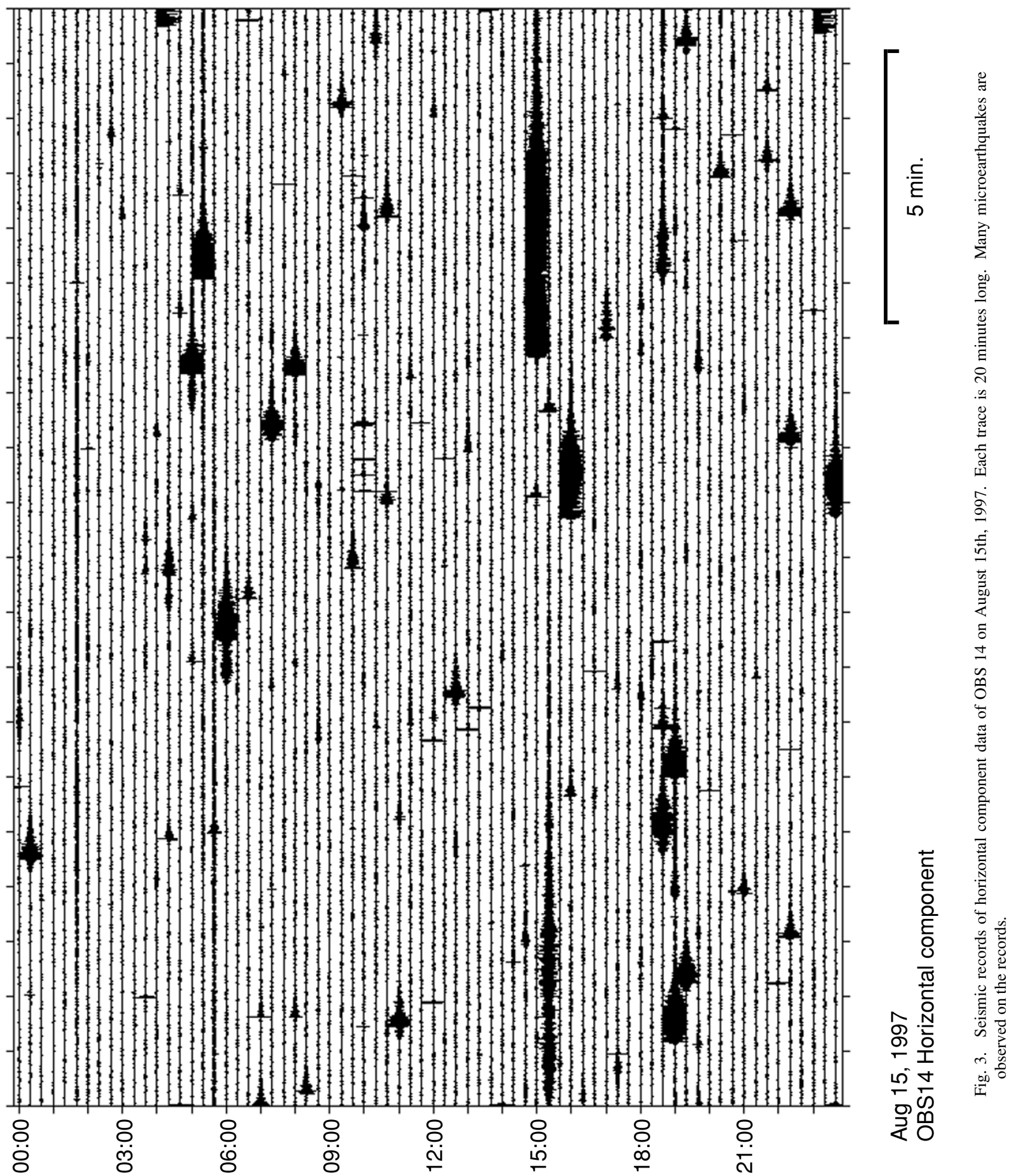




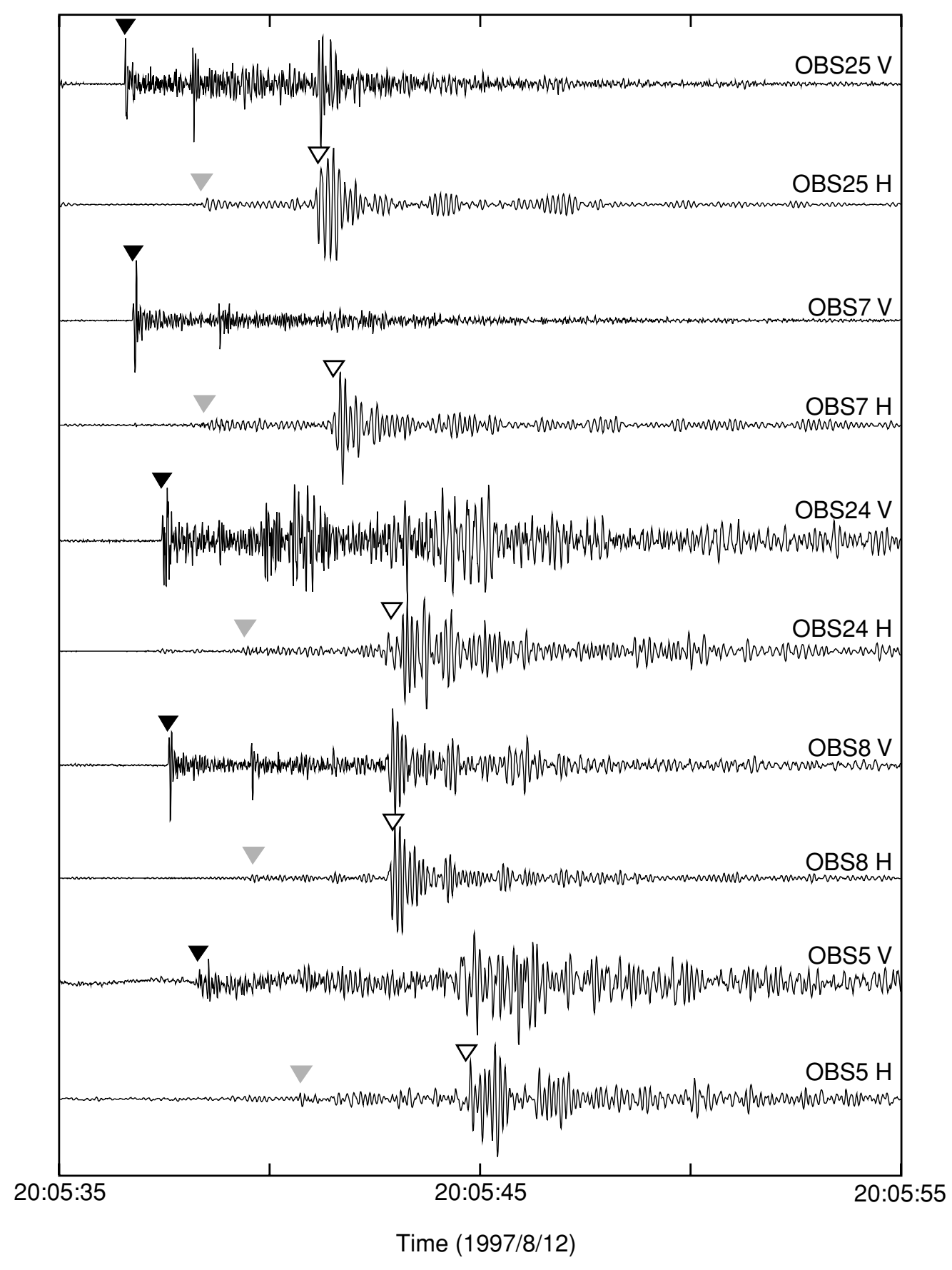

Fig. 4. Example of OBS seismograms for a single earthquake. The vertical component and one horizontal component are shown. The origin time of the event is 20:5:32.0 JST on August 12th 1997 and the estimated coordinate of the hypocenter is $37^{\circ} 11.8^{\prime} \mathrm{N}, 142^{\circ} 04.3^{\prime} \mathrm{E}$. The depth and magnitude of the event are $23.7 \mathrm{~km}$ and 2.1 , respectively. Each trace is normalized by its maximum amplitude. The OBS number is labeled above each trace. $\mathrm{V}$ and $\mathrm{H}$ denote vertical component and horizontal components of the seismogram, respectively. Solid and open inverted triangles indicate $\mathrm{P}$ and $\mathrm{S}$ wave arrivals, respectively. Gray triangles denote arrivals of $\mathrm{P}$ to $\mathrm{S}$ conversion phase at an acoustic basement just below each OBS.

a least squares method using travel time data derived from the direct water waves generated by the airguns. A crystal oscillator in the data recorder controlled the timing of each OBS, and times were adjusted to GPS time by measuring the difference between the OBS clocks and GPS time both before and after the observation period and calibrated assuming a linear drift. The accuracy of timing in the records throughout the observation period is estimated to be better than $0.05 \mathrm{~s}$.

\section{Data Analysis}

First, we plotted all horizontal seismograms for the whole observation period (e.g. Fig. 3) and then manually selected events. We then extracted the selected events from each continuous OBS dataset. The event data were assembled to make a multi-station data file (Fig. 4). P- and S-wave arrival times were picked on a computer display (Urabe and Tsukada, 1992). We also picked arrival times of converted waves and measured signal duration time. Reading errors between $0.01 \mathrm{~s}$ and $1.0 \mathrm{~s}$ were also estimated for each reading. We detected a total of 1973 events, with 596 of these 


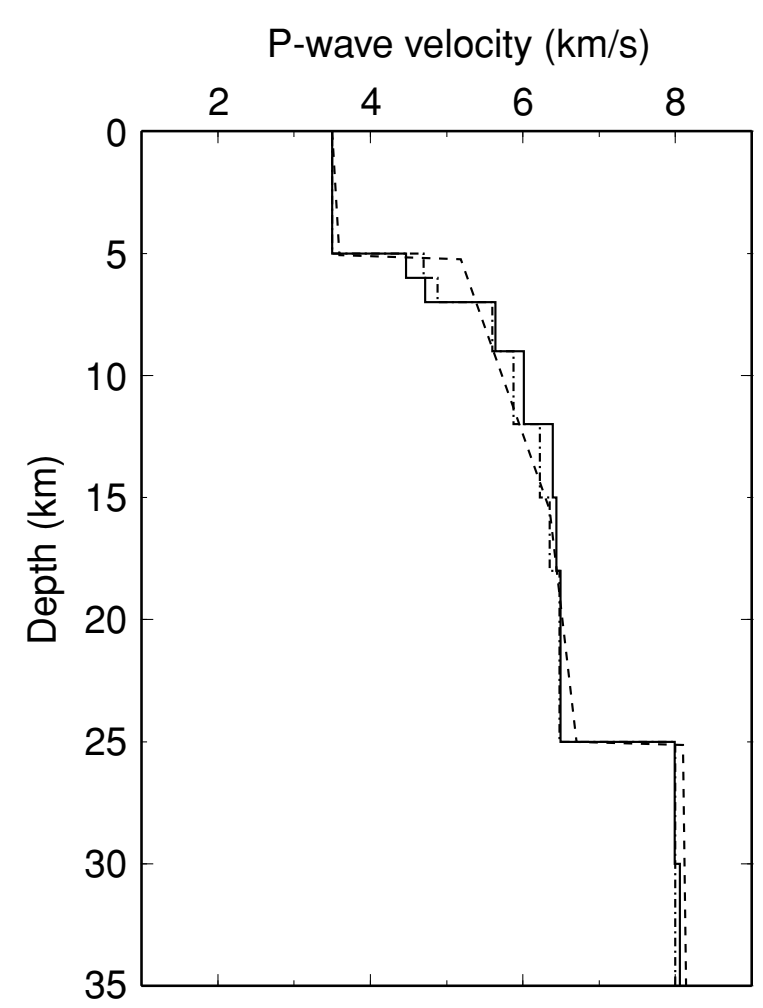

Fig. 5. P-wave velocity structure models for the hypocenter determinations. The model shown by the dashed line was used for the first hypocenter determination and was derived from the refraction experiment carried out using the same OBSs in 1997 (Nishino, 1999) and another experiment in 1998 (Miura et al., 2003). The dot-dashed line and thick line indicate the initial velocity model for the simultaneous inversion and the result of the inversion, respectively.

recorded by at least three OBSs.

The magnitude of the detected earthquakes was estimated by a simple empirical law using the signal duration time (Tsumura, 1967). The magnitudes were calculated for each OBS, and the average value was adopted as the magnitude of the event. The OBS array detected earthquakes with magnitudes ranging from $0.8-4.2$, with the majority of the earthquakes having magnitude $\sim 2$. One of the 596 events was too small to determine magnitude.

Hypocenters were estimated using the maximumlikelihood estimation of Hirata and Matsu'ura (1987) for initial locations. The location program uses a $1-\mathrm{D}$ velocity structure for travel time estimation. A simple velocity structure for the hypocenter location was modeled using the results of the refraction study carried out at the beginning of the earthquake observation period (Nishino, 1999) as well as the results of another airgun/OBS seismic refraction experiment (Miura et al., 2003). The crust was assigned two layers: a $5.2-\mathrm{km} / \mathrm{s}$ layer and a $6.4-\mathrm{km} / \mathrm{s}$ layer. The total igneous crustal thickness is about $20 \mathrm{~km}$ and the underlying Pn velocity is $8.0 \mathrm{~km} / \mathrm{s}$ (Fig. 5). We assumed a ratio of Pwave to $\mathrm{S}$-wave velocity in the crust and mantle of 1.73 , as $\mathrm{S}$-wave velocities in the lower crust and mantle for this region are not known. Since the thickness of the sedimentary layers changes at each OBS site, the travel times estimated by the location program must be corrected using the time difference between the P wave arrival and the PS converted wave arrival, thickness of the sedimentary layer, and $\mathrm{P}$ wave velocity of the sedimentary layer (Fig. 4). Because each OBS was also used for the seismic surveys (Nishino, 1999), we were able to estimate accurate values for the required time correction.

Because the velocity structure in the study region may be heterogeneous due to the subduction of the Pacific plate, we estimated final hypocenter locations using a simultaneous inversion of hypocenter locations and a onedimensional velocity structure (Kissling et al., 1994). We used the results of the first hypocenter determination as initial hypocenters for the inversion. A starting velocity structure was modeled by using the one-dimensional velocity structure just below OBS No. 13 in Miura et al. (2003) (Fig. 5). Although the inversion is capable of determining suitable station correction values, we used the correction values from the converted waves as fixed values. We also maintained the assumption that the $\mathrm{Vp} / \mathrm{Vs}$ ratio is 1.73 . After three iterations, the root mean square residual of travel times decreased from $0.53 \mathrm{~s}$ to $0.45 \mathrm{~s}$ and the velocities at depths less than $20 \mathrm{~km}$ decrease (Fig. 5), indicating convergence to a stable solution.

\section{Results}

Seismic activity in the surveyed area did not change appreciably in terms of number or magnitude of events over the duration of the experiment. OBSs in the southern region recorded higher seismic activity than those in the northern area. This is consistent with the observation that the OBSs in the southern area recorded a large number of events with small S-P time (4-7 s). Among the 505 located events, 401 earthquakes have location errors less than $3 \mathrm{~km}$ in the horizontal direction and less than $5 \mathrm{~km}$ in depth. To evaluate the performance of the location algorithm, we calculated an error ellipse of initial hypocenters from the total covarience matrix of the location program (Hirata and Matsu'ura, 1987) for all determined events (Fig. 6). Small error ellipses for events inside the OBS array indicate high performance of the OBS array, and confirm the potential to precisely locate microearthquakes. The relatively large error ellipses for events outside the OBS array indicate poorly resolved solutions.

Figure 7 shows the final locations of the 401 selected events and the OBS positions. Our results clearly show spatial heterogeneity of seismic activity. There are two groups of earthquakes: 389 earthquakes occurred shallower than $40 \mathrm{~km}$ and 12 earthquakes occurred deeper than $40 \mathrm{~km}$. The depths of the earthquakes in the deep group are also confirmed by a comparison of S-P times between the two groups (Fig. 8). The microseismicity in the shallow earthquake group is bounded on the east by the landward wall of the trench. In addition, there appear to be two seismic planes in the shallow earthquake group. The eastern edge of seismic activity coincides with the $2000 \mathrm{~m}$ isobath, and is about $100 \mathrm{~km}$ west of the trench axis. At the seismic front in the southern area, the hypocenters are approximately 20 $\mathrm{km}$ deep. In contrast, the eastern edge of the active seismic region is found at about $25 \mathrm{~km}$ depth in the northern area where seismic activity is relatively low. The deeper group of earthquakes forms a landward dipping plane and extends 

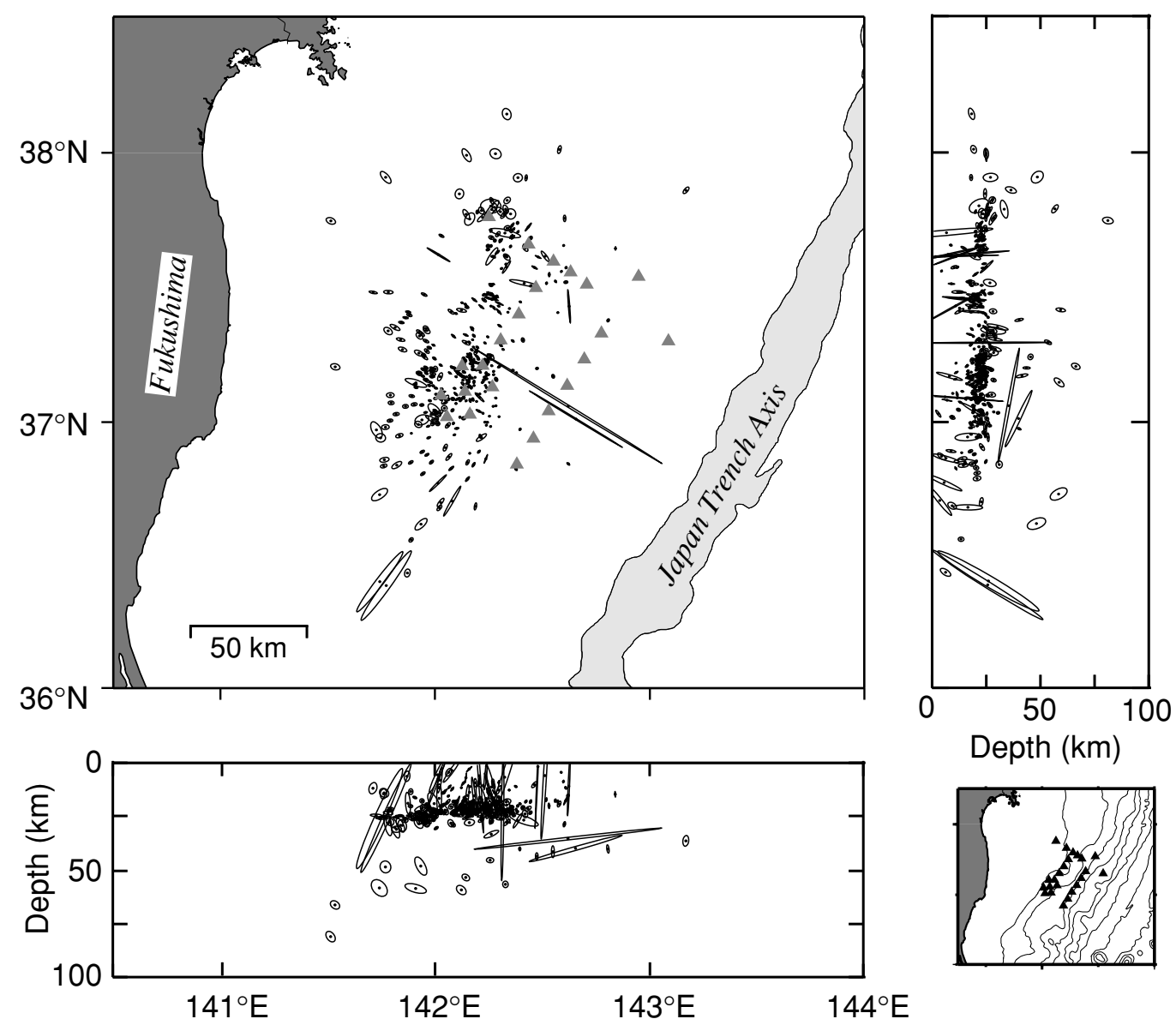

Fig. 6. The distribution of all located earthquakes from the results of the first simple determination with error ellipses. The light gray area indicates the trench axis where the water depth is greater than $7000 \mathrm{~m}$. Vertical sections along latitude (right) and longitude (lower) are also shown. Lower left; positions of OBS are denoted by solid triangles.

eastward to within $\sim 70 \mathrm{~km}$ of the trench axis, closer to the trench axis than the upper group.

\section{Discussion}

\subsection{Earthquake locations and spatial distribution of earthquakes}

The hypocenters can be compared to a crustal velocity structure obtained by the airgun-OBS survey carried out in 1998 (Miura et al., 2003) (Fig. 9). Almost all the hypocenters in the upper seismic group are concentrated in the vicinity of the plate boundary interface as determined by the seismic structure survey. The depth distribution of earthquakes located near the plate boundary fall within a window $\sim 10$ $\mathrm{km}$ in height around the plate boundary. At the seismic front, the mean hypocentral depth is approximately $20 \mathrm{~km}$. The seaward limit of the high seismicity region along the plate boundary is located in the vicinity of a region where the subducting oceanic crust is thought to contact the landward upper mantle (Nishino, 1999; Miura et al., 2003).

The dip angle of the subducting plate at distances of greater than $120 \mathrm{~km}$ landward from the trench axis appears to be different from that found in the high seismic activity zone. However, the earthquakes in this deep region are expected to occur near the plate boundary due to the occurrence of low-angle thrust type focal mechanisms. Miura et al. (2003) showed that the resolution of the dip angle esti- mates from the seismic survey in this deep region are not sufficient to resolve small dip variations, in addition, the airgun profile did not run all the way across the OBS observation area (Fig. 2). On the other hand, the hypocenters were estimated using the 1-D velocity structure which has a crustal thickness of $25 \mathrm{~km}$ and P-wave velocity of $6.4 \mathrm{~km} / \mathrm{s}$ in the lower crust (Fig. 5). From the result of the seismic survey (Miura et al., 2003), the Moho interface of the landward plate lies at depth of approximately $20 \mathrm{~km}$ (Fig. 9). Therefore, we infer two possibilities for the observed inconsistency in dip angle: the dip angle of the subducting plate estimated from the seismic survey is too steep, or the depths of the earthquakes in the mantle of the landward plate are systematically estimated to be shallower than actual depths.

Within the overriding landward crust, earthquakes were observed at a depth range of $5 \mathrm{~km}$ to $15 \mathrm{~km}$. This seismic activity is clearly separate from that in the vicinity of the plate boundary. The lower seismic group of earthquakes occurred in the upper mantle of the subducting Pacific plate. 5.2 Seismic coupling at the plate boundary

A thick, low velocity interplate layer was detected by both the airgun-OBS experiment (Miura et al., 2003) and a multi-channel seismic survey (Tsuru et al., 2002). Miura et al. (2003) estimated that the interplate layer has a P-wave velocity of $4 \mathrm{~km} / \mathrm{s}$ and a thickness of $\sim 1 \mathrm{~km}$. The interplate layer was also observed in an airgun-OBS survey by 


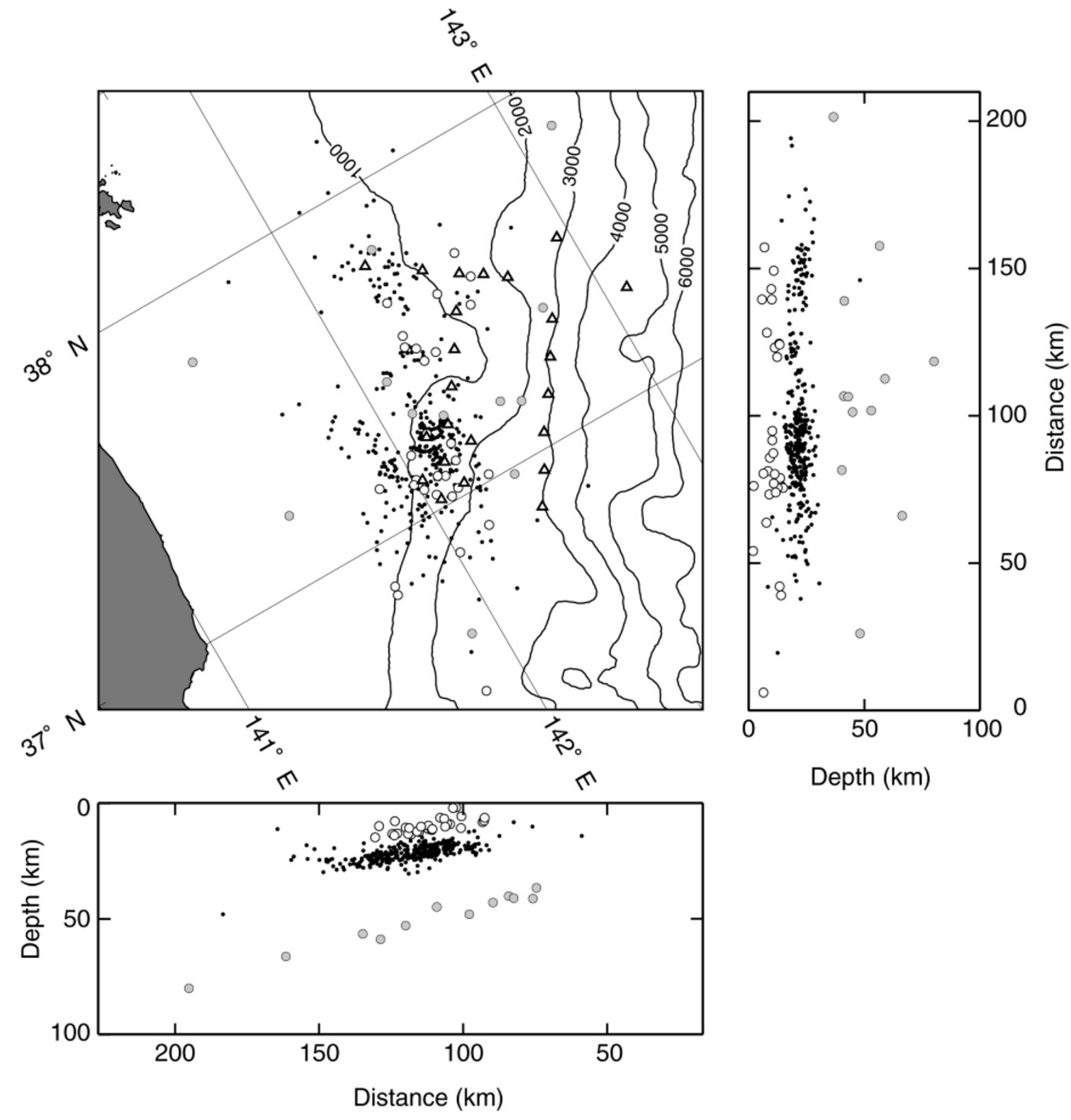

Fig. 7. Final hypocenter distribution (August 8th-August 24th, 1997) arrived at using the simultaneous inversion with bathymetry. Earthquakes with an error of less than $3 \mathrm{~km}$ for the horizontal direction and less than $5 \mathrm{~km}$ in depth are selected for the simultaneous inversion. Open circles and black dots show hypocenters in the overriding landward crust and in the vicinity of the plate boundary interface, respectively. Gray circles represent hypocenters in the lower plane of the double seismic zone within the subducting slab. Triangles indicate the positions of OBSs. A double seismic zone is clearly recognized in the vertical section perpendicular to the trench axis.

Nishino (1999). The low velocity interplate layer is interpreted as underthrusted sediment (Miura et al., 2003). The width of the aseismic zone along the plate boundary interface determined by our study seems to be bounded by the interplate layer. In addition, plate boundary segments associated with the interplate layer do not seem to correlate with the inferred source regions of the 1938 large earthquakes. Subducting sediments are interpreted to cause weakening of seismic coupling between the overriding landward plate and the oceanic plate (von Huene et al., 1994). This may reflect seismic coupling changes at the eastern edge of the high seismicity region.

At the toe of the mantle wedge, a partial decrease of Pwave velocity to $7.4 \mathrm{~km} / \mathrm{s}$ was observed during a controlled seismic experiment (Miura et al., 2003). This low velocity mantle wedge is consistent with results of earthquake tomographic studies (e.g. Zhao et al., 1994). Miura et al. (2003) suggested that the low velocity mantle wedge indicates the presence of serpentinized mantle materials. In the Izu-Ogasawara arc, the presence of serpentinized mantle wedge was interpreted (e.g. Suyehiro et al., 1996) and serpentines were dredged in the trench area (Fujioka et al., 1995). Hyndman et al. (1997) suggested that seismic activity decreases or disappears along plate boundary interfaces where the mantle wedge is serpentinized. However, our results show that the plate boundary region, where the subducting Pacific plate is in contact with the low velocity mantle wedge, has high seismic activity. In order to ex- 


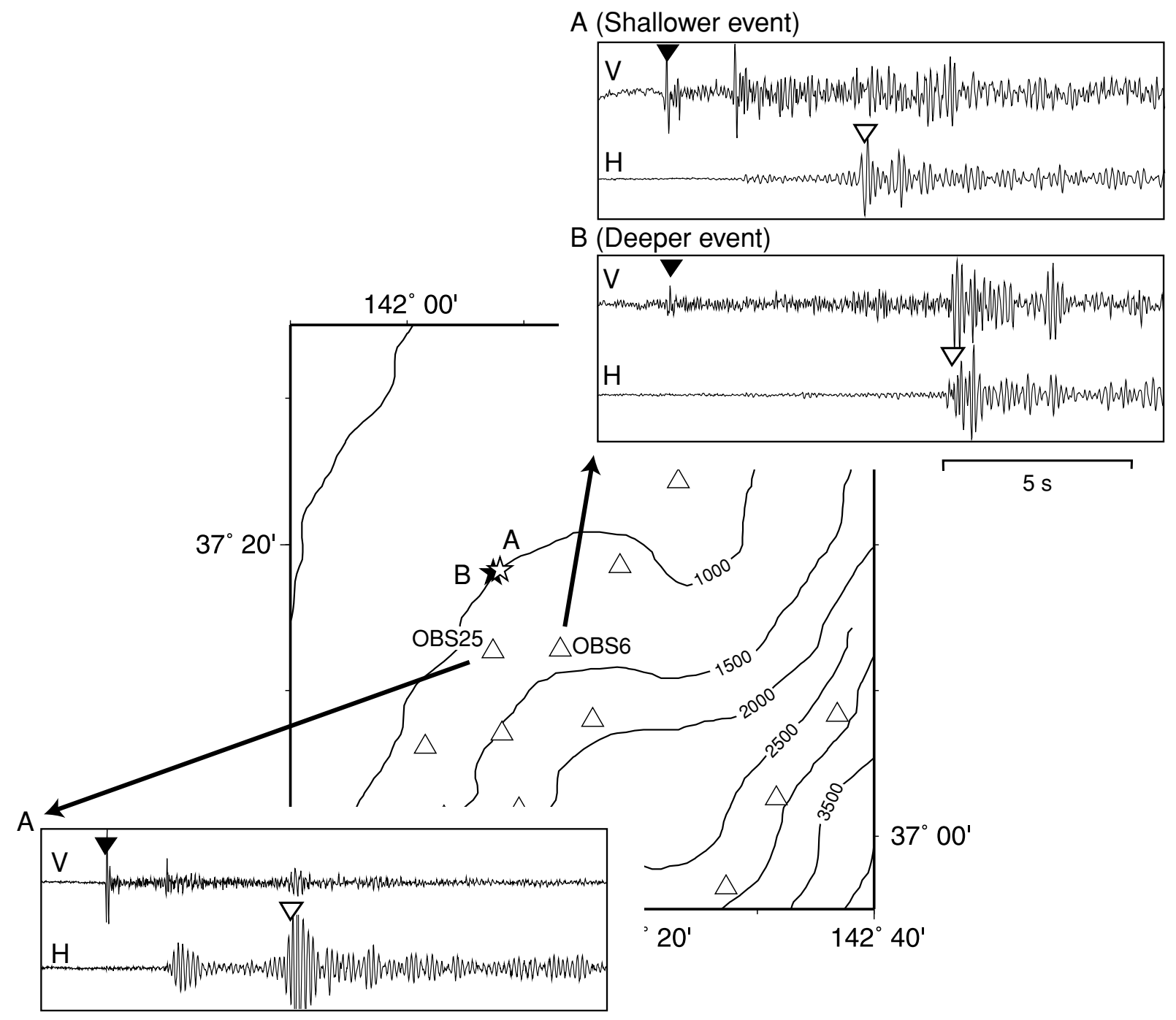

B

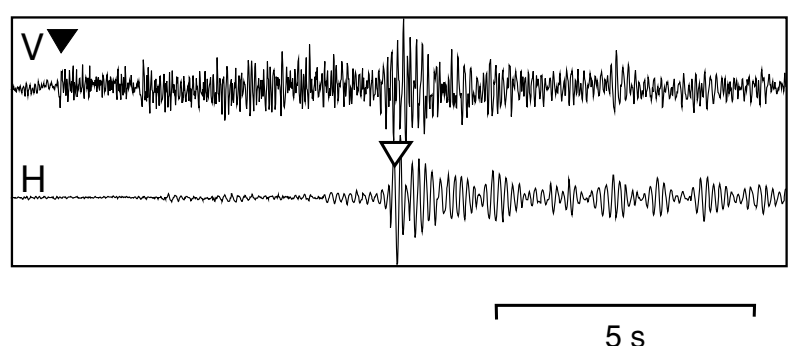

Fig. 8. Comparison of S-P times for earthquakes that have almost the same epicenter but different depths. Triangles denote the positions of OBSs. Solid star (A) and open star (B) indicate epicenters of earthquakes in the upper seismic zone and the lower seismic zone within the slab, respectively. The waveforms of events recorded by OBS 6 and OBS 26 are shown. Solid inverted triangles and open inverted triangles indicate arrivals of P-waves and $\mathrm{S}$-waves, respectively. The S-P times of earthquakes in the lower seismic zone are larger than those of the events in the upper seismic zone.

amine whether earthquakes occur at the plate boundary interface, we determined focal mechanisms using the OBS data. Eleven focal mechanisms were obtained by using the computer program described in Reasenberg and Oppenheimer (1985). Figure 10 shows the distribution of epicenters for which we could compute the focal mechanisms. The depth of the events is less than $40 \mathrm{~km}$. We also plot the focal solutions determined by the automated moment tensor determination using Japanese land seismic network data (Fukuyama et al., 1998). Events selected had depths less than $40 \mathrm{~km}$ and variance reduction greater than 0.9 , and were limited to a period from 1997 to 2003 . The magnitude of events ranges from 4.7 to 6.8. Most of the events occurring near the seismic front have reverse faulting mechanisms. In contrast, the events near the zone of direct contact between the subducting Pacific plate and the mantle of the overriding landward plate have both reverse- and normaltype focal mechanisms. In 1938, five large earthquakes with magnitudes greater than seven occurred in the southwestern part of the study area (Fig. 1). Abe (1977) reported that these five earthquakes consisted of a low-angle thrust type and a normal-fault type. The low-angle thrust earthquakes 


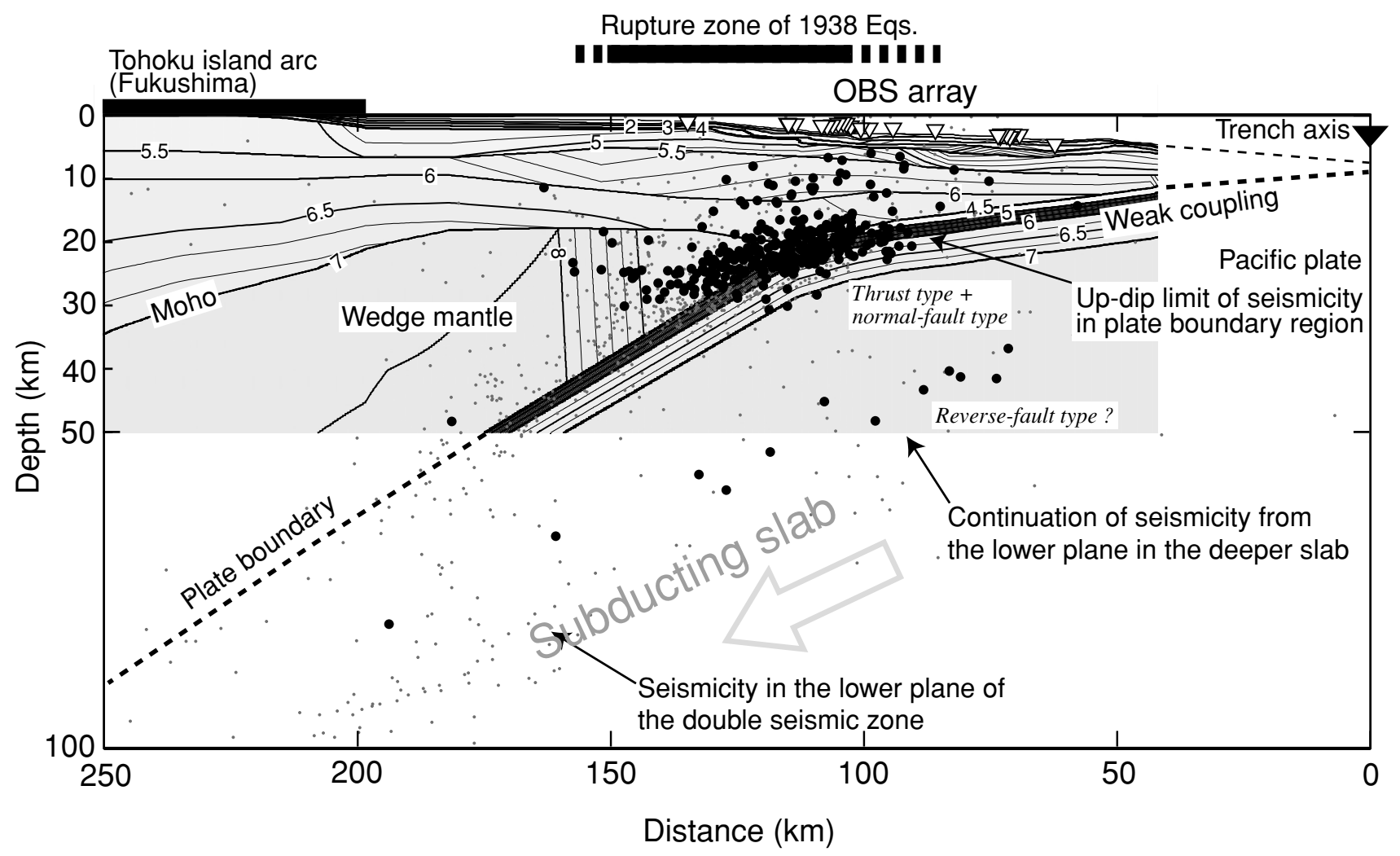

Fig. 9. Comparison with P-wave velocity structure of the subduction zone off Fukushima, the Japan Trench (Miura et al., 2003). Contours and numerals indicate P-wave velocities. Solid circles and gray small circles show the hypocenters determined by this study and by land stations with a single offshore station (Igarashi et al., 1996, 1997), respectively. Thick solid line at top shows the source regions of large thrust-type earthquakes in 1938 (Abe, 1977). The up-dip limit of the seismogenic zone is close to the major bending point of the subducting oceanic plate. In addition, there is seismic activity in the crust of the overriding landward plate. The lower seismic zone beneath the OBS array recognized by this study seems to be continuous with the lower plane of the double-planed deep seismic zone determined from land stations.

are considered to represent slip along the plate boundary interface (Fig. 9). Other events were interpreted as large normal-fault earthquakes within the subductng Pacific plate. The existence of events with reverse-fault mechanisms from our data indicates that these earthquakes occur at the plate boundary interface beneath the overall high seismic activity area in the plate boundary region. The source area of the 1938 large earthquakes also coincides with the southern half of the high seismic activity area determined by the OBS array used in this study. These indicate that seismic coupling is not weak even in the zone of direct contact between the subducting Pacific plate and the mantle of the overriding landward plate. The normal-fault earthquakes indicate that seismic activity also occurs in the subducting Pacific plate. Thus, we recognize that the high seismic activity close to the plate boundary interface includes both interplate-type and intraplate type earthquakes.

The seismic structure surveys conducted with controlled sources show a rapid change of dip angle of the subducting Pacific plate at a distance of $\sim 110 \mathrm{~km}$ landward of the trench axis (Nishino, 1999; Miura et al., 2003). We infer that the abrupt increase of the dip angle of the subducting plate causes the normal-fault earthquakes in the subducting plate. Within the overriding landward crust, 29 earthquakes occurred between 5 to $15 \mathrm{~km}$ depths. This seismic activity is clearly distinguished from activity in the vicinity of the plate boundary interface by the contrast in depth ranges.
Seismic activity in the overriding landward plate may relates to the stress distribution in the crust of the landward plate caused by the rapid increase of the dip angle of the subducting Pacific plate and the variation of physical property in the crust of the landward plate. To clarify the origin of this seismic activity, more information is needed such as more precise hypocenter locations, focal mechanisms and geophysical structures of the crust.

\subsection{Up-dip extension of lower seismic plane in the dou- ble seismic zone}

Based on a comparison of hypocenter distribution and seismic structure (Miura et al., 2003), we recognize seismic activity below the oceanic crust within the subducting plate (Fig. 9). These earthquakes form a landward dipping plane, with an up-dip limit of this westward dipping plane found at $\sim 40 \mathrm{~km}$ depth $(\sim 70 \mathrm{~km}$ landward of the trench axis). Although offshore earthquakes in the deeper part of the subducting slab have been located using the land seismic network, their hypocenter depths were not well constrained due to the lack of adequate seismic station coverage in marine areas.

Beneath the Tohoku island arc, at intermediate-depths within the subducting slab, Hasegawa et al. (1978a) interpreted a double seismic zone. The double seismic zone exists at a depth range of $50 \mathrm{~km}$ to $200 \mathrm{~km}$, consisting of two parallel planes separated by a depth of 30 to 40 $\mathrm{km}$. Focal mechanisms in the upper plane and the lower 

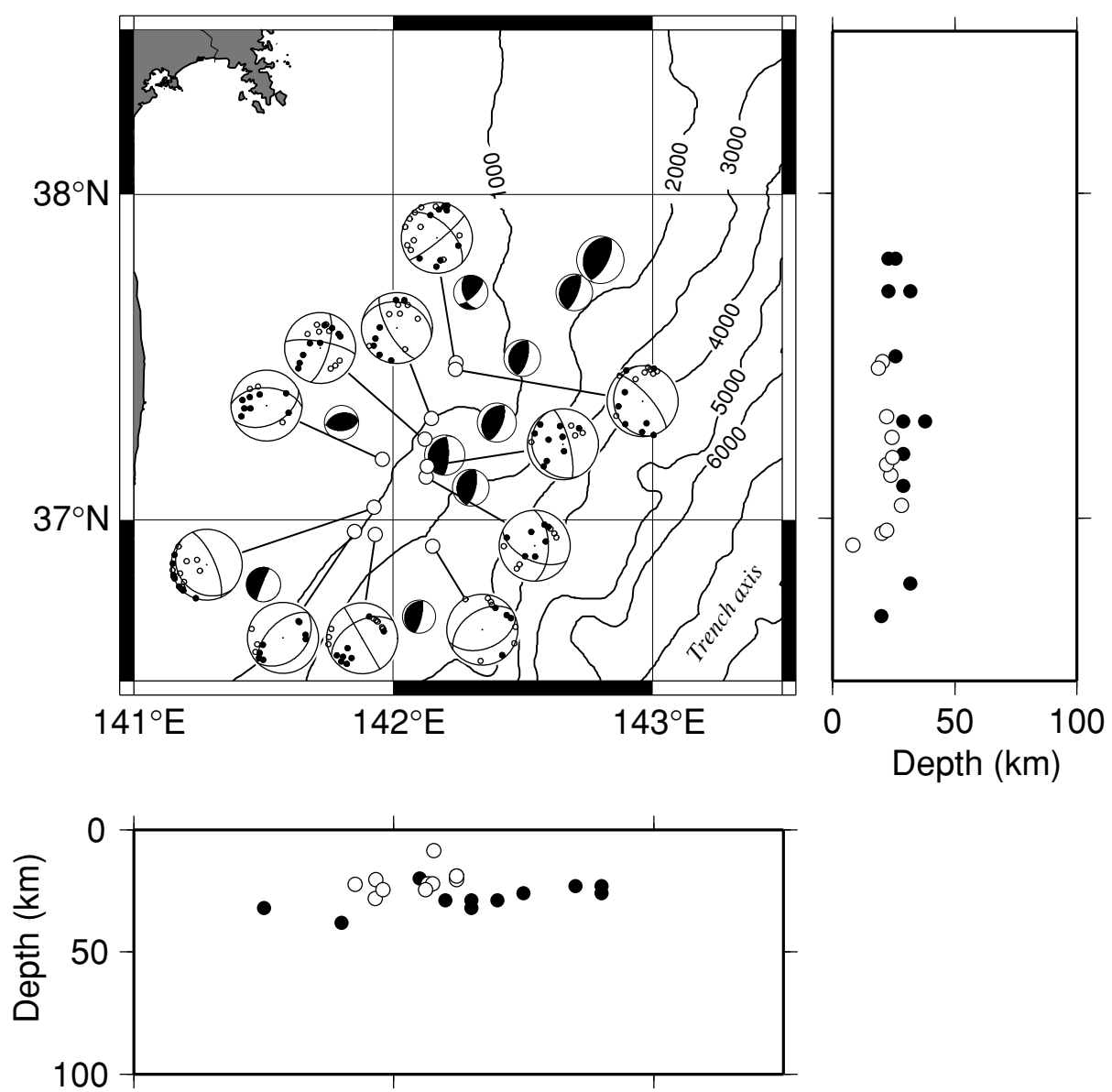

Fig. 10. Distribution of focal mechanism solutions determined by using polarities of first arrivals recorded by the OBSs and the automated moment tensor determination using Japanese land seismic network data (Fukuyama et al., 1998). Lower hemisphere equal area projection was used. Open circles indicate the positions of earthquakes whose focal mechanism solutions were determined by the OBS array. Focal mechanism solutions plotted by solid black and white were obtained by the automated moment tensor determination and the plotting positions denote the epicenters. Solid circles in the vertical profiles show the position of the events of the moment tensor determination. The events with depth less than $40 \mathrm{~km}$ and variance reduction greater than 0.9 from 1997 to 2003 were selected from the results of the moment tensor determination. Although most of the events show reverse-fault type mechanism, the events with normal-fault type mechanism also occurred.

plane show down-dip compression and down-dip extension, respectively. Seismicity in the upper plane is higher than that found in the lower plane. Similar double seismic zones found at intermediate depths and associated with deep earthquakes have been found in the other parts of the Japan Trench subduction zone as well as subduction zones such as the Kuriles, New Britain, Tonga, Chile, and the Aleutians. In northeast Japan, earthquakes in the lower plane begin to occur at a depth of $\sim 60 \mathrm{~km}$.

Accurate hypocenter distribution beneath the Tohoku area can be determined because of the densely distributed land seismic stations. The planar seismic zone determined by our OBS observations in the upper mantle within the slab is interpreted as an up-dip extension of the lower seismic plane of the double seismic zone determined by the land seismic network. Nishizawa et al. (1990b) reported two intermediate-depth earthquakes that took place along the lower plane of the double seismic zone as defined by the OBS observations, and concluded that the lower plane seismic activity can be found about $110 \mathrm{~km}$ landward of the trench axis. From our results, seismic activity along the lower plane in the double seismic zone beneath Tohoku, Japan, exists at least up to $70 \mathrm{~km}$ landward of the trench axis and up to a depth of $\sim 40 \mathrm{~km}$. In addition, the earthquakes in the upper mantle clearly form a plane (Fig. 9). In the northern Japan Trench region off Sanriku, activity along the lower seismic plane of the double seismic zone starts approximately $100 \mathrm{~km}$ landward of the trench axis. Hino et al. (2000) observed aftershocks associated with the 1994 Sanriku-oki earthquake by using 18 OBSs, during a 1 month long observation period. The plate boundary was clearly imaged using their OBS observations. However, no earthquakes deeper than $40 \mathrm{~km}$ were observed in the area within $100 \mathrm{~km}$ distance from the trench axis.

The double-planed seismic zone has been interpreted as the result of a wide variety of mechanical processes, including unbending stresses (Engdahl and Scholz, 1977), sagging stresses (Sleep, 1979), thermal stresses (House and Jacob, 1982; Hamaguchi et al., 1983) or dehydration embrittlement (Seno and Yamanaka, 1996; Seno et al., 2001). Although we were not able to determine exact focal mechanisms for the earthquakes that occurred along the lower seismic plane because of insufficient OBS network coverage, we infer, based on the polarity distributions of first arrivals, that most of these earthquakes have reverse-fault focal mechanisms, consistent with the dehydration embrit- 
tlement mechanism (Seno and Gonzales, 1987; Seno et al., 2001). There are many seamounts seaward of the trench axis off Fukushima (Fig. 1), indicating that the upper mantle in the subducting Pacific plate may be hydrated due to past volcanic activity (e.g. Seno and Yamanaka, 1996). The sharp bending of the subducting Pacific plate at $110 \mathrm{~km}$ landward of the trench should apply a moment to the hydrated oceanic plate and reverse-type earthquakes occur in the deeper region by dehydration embrittlement of serpentinized mantle. Because the earthquakes in the lower seismic plane deeper than $60 \mathrm{~km}$ have focal mechanisms indicative of down-dip extension, we expect changes with depth in the focal mechanisms of earthquakes along the lower seismic plane.

\section{Conclusions}

We performed microearthquake observations using twenty-seven OBSs along the landward slope of the Japan Trench off Fukushima in the summer of 1997. The region off Fukushima has very high seismicity, with magnitudes ranging from less than 1 to 6 . The purposes of the OBS observations were to obtain precise hypocenter distributions and to provide detailed data regarding the characteristics of the observed seismicity. The hypocenters of 401 earthquakes were obtained with an error of less than $3 \mathrm{~km}$ in the horizontal direction and less than $5 \mathrm{~km}$ in depth during the $\sim 1$-month observation period. Hypocentral distributions have high spatial resolution: the crustal velocity structure used for locating events was determined using concurrent and previous airgun-OBS surveys in the study area and the hypocenter distribution was obtained using the simultaneous inversion of hypocenters and a one-dimensional velocity structure. The following observations and conclusions were obtained from this investigation:

- Microearthquake seismicity was stable over the period of observation.

- The magnitudes of the well-determined events ranged from 0.8 to 4.2 .

- Almost all hypocenters were located in the vicinity of the plate boundary interface as delineated by seismic structure surveys.

- The thickness of the seismic zone along the plate boundary interface is approximately $10 \mathrm{~km}$.

- The seismic front along the plate boundary interface occurs at a distance of $100 \mathrm{~km}$ landward of the trench axis.

- At the seismic front, the depth of the hypocenters is approximately $20 \mathrm{~km}$, which corresponds to the depth of the plate boundary interface.

- From focal mechanisms of earthquakes, we estimate that the coupling between the subducting plate and the overriding landward plate is not weak beneath the OBS network and there is intraplate-type earthquake activity in the subducting plate due to an abrupt increase of the dip angle of the subducting plate.
- Twenty-nine earthquakes were located within the overriding landward plate, ranging in depth from 5 to 15 $\mathrm{km}$. This shallow seismic activity is clearly spatially distinguishable from the activity in the vicinity of the plate boundary interface.

- Twelve earthquakes were located about $30 \mathrm{~km}$ below the plate boundary, and form a landward dipping plane. The plane is interpreted as an up-dip extension of the lower seismic plane of the double seismic zone within the slab observed by the land networks. The seismic activity along the lower plane in the double seismic zone beneath the middle part of the Tohoku, Japan, area extends eastward to at least $70 \mathrm{~km}$ landward of the trench axis and upward to depths of $\sim 40 \mathrm{~km}$. We suggest that a moment stress due to abrupt bending of the subducting plate combined with dehydration embrittlement processes in serpentinized oceanic mantle are primary factors in earthquake occurrence and character along this lower seismic zone beneath the forearc.

Acknowledgments. The authors acknowledge Profs. T. Kanazawa, J. Kasahara, and H. Shiobara for enlightening discussions and support of this study. The work of the captain, officers, and crew of M/V Shin'nichi-maru is appreciated. Comments by Drs. T. Eguchi, E. R. Flueh, and E. Fukuyama helped us improve the manuscript. Discussions with Drs. K. Mochizuki, G. Fujie, Y. Aoyagi, Y. Asano, Y. Yabe, and Mr. S. Koresawa were helpful for the data processing and data interpretation. We also thank Dr. R. A. Stephen for critical reading of the manuscript, and Dr. T. Yamada and Mr. S. Nagai for introducing computer programs. Dr. S. Miura provided us information of the seismic velocity structure kindly. The comments by Dr. Daniel Curewitz were also helpful for improving English of this manuscript. A part of the observation for this study was carried out in cooperation with Tokyo Electric Power Company Inc. and Tohoku Electric Power Company Inc. Many of the figures were created using GMT (Wessel and Smith, 1998).

\section{References}

Abe, K., Tectonic implications of the large Shioya-Oki earthquakes of 1938, Tectonophysics, 41, 269-289, 1977.

Aoyagi, Y., Seismicity around plate boundary off Fukushima using earthquakes with similar waveforms, D. Sc. thesis, Chiba Univ., pp. 107, 1999 (in Japanese).

DeMets, C., R. G. Gordon, D. F. Argus, and S. Stein, Current plate motions, Geophys. J. Int., 101, 425-278, 1990.

DeMets, C., R. G. Gordon, D. F. Argus, and S. Stein, Effect of recent revisions to the geomagnetic reversal time scale on estimates of current plate motions, Geophys. Res. Lett., 21, 2191-2194, 1994.

Engdahl, E. R. and C. H. Scholz, A double Benioff zone beneath the central Aleutians: An unbending of the lithosphere, Geophys. Res. Lett., 4, 473476, 1977.

Fujie, G., J. Kasahara, R. Hino, T. Sato, M. Shinohara, and K. Suyehiro, A significant relation between seismic activities and reflection intensities in the Japan Trench region, Geophys. Res. Lett., 29, 10.1029/2001GL013764, 2002.

Fujioka, K., T. Tanaka, and K. Aoike, Serpentine seamount in Izu-Bonin and Mariana forearcs-observation by a submersible and its relation to onland serpentinite belt, J. Geogr., 104, 473-494, 1995.

Fukuyama, E., M. Ishida, D. S. Dreger, and H. Kawai, Automated seismic moment tensor determination by using on-line broadband seismic waveforms, Zisin, 51, 149-156, 1998 (in Japanese with English abstract).

Hamaguchi, H., K. Goto, and Z. Suzuki, Double-planed structure of intermediate-depth seismic zone and thermal stress in the descending plate, J. Phys. Earth, 31, 329-347, 1983.

Hasegawa, A., N. Umino, and A. Takagi, Double-planed structure of the deep seismic zone in the northeastern Japan Arc, Tectonophysics, 47, 43-58, 1978a. 
Hasegawa, A., N. Umino, and A. Takagi, Double-planed deep seismic zone and upper-mantle structure in the northeastern Japan Arc, Geophys. J. R. Astron. Soc., 54, 281-196, 1978 b.

Hasegawa, A., S. Horiuchi, and N. Umino, Seismic structure of the northeastern Japan convergent margin: A synthesis, J. Geophys. Res., 99, 22295-22312, 1994.

Hino, R., T. Kanazawa, and A. Hasegawa, Interplate seismic activity near the norhern Japan Trench deduced from ocean bottom and land-based seismic observations, Phys. Earth Planet. Inter., 93, 37-52, 1996.

Hino, R., S. Ito, H. Shiobara, H. Shimamura, T. Sato, T. Kanazawa, J. Kasahara, and A. Hasegawa, Aftershock distribution of the 1994 Sanriku-oki earthquake (Mw 7.7) revealed by ocean bottom seismographic observation, J. Geophys. Res., 105, 21697-21710, 2000.

Hirata, N. and M. Matsu'ura, Maximum-likelihood estimation of hypocenter with origin time eliminated using nonlinear inversion technique, Phys. Earth Planet. Inter., 47, 50-61, 1987.

Hirata. N., T. Yamada, H. Shimamura, H. Inatani, and K. Suyehiro, Spatial distribution of microearthqukaes beneath the Japan Trench from ocean bottom seismographic observartions, Geophys J. R. Astron. Soc., 73, 653-669, 1983.

Hirata, N., T. Kanazawa, K. Suyehiro, and H. Shimamura, A seismicity gap beneath the inner wall of the Japan Trench as derived by ocean bottom seismograph measurement, Tectonophsics, 112, 193-209, 1985.

Hirata, N., T. Kanazawa, K. Suyehiro, T. Iwasaki, and H. Shimamura, Observations of microseismicity in the southern Kuril Trench area by arrays of ocean bottom seismometers, Geophys. J. Int., 98, 55-68, 1989.

House, L. S. and K. H. Jacob, Thermal stresses in subducting lithosphere can explain double seismic zone, Nature, 295, 587-589, 1982.

von Huene, R., D. Klaeschen, and B. Cropp, Tectonic structure across the accretionary and erosional parts of the Japan Trench margin, J. Geophys. Res., 99, 22349-22361, 1994.

Hyndman, R. D., M. Yamano, and D. A. Oleskevich, The seismogenic zone of subduction thrust faults, Island Arc, 6, 244-260, 1997.

Igarashi, T., R. Hino, T. Matsuzawa, A. Yamamoto, T, Okada, S. Ito, and A. Hasegawa, Hypocenter relocation of events off Fukushima Prefecture by using OIP station data, Abst. Seismo. Soc. of Jpn. Mtg, 2, C80, 1996 (in Japanese).

Igarashi, T., R. Hino, T. Okada, T. Matsuzawa, and A. Hasegawa, Estimation of focal mechanisms of earthquakes off Fukushima Prefecture, $A b$ str. Jpn Earth and Planet. Sci. Joint Mtg, W12-P15, 1997 (in Japanese).

Iwasaki, T., N. Hirata, T. Kanazawa, T. Urabe, Y. Motoya, and H. Shimamura, Earthquake distribution in the subduction zone off eastern Hokkaido, Japan, deduced from ocean-bottom seismographic and land observations, Geophys. J. Int., 105, 693-711, 1991.

Kanazawa, T. and H. Shiobara, Newly developed Ocean-bottom seismometer, Abstr. Jpn Earth and Planet. Sci. Joint Mtg, I11-P82, 1994 (in Japanese).

Kasahara, J., S. Nagumo, S. Koresawa, Y. Nishi, and H. Sugimoto, A linear trend of hypocenter distribution in the outer slope region of the Japan Trench revealed by OBS array: Preliminary report, Bull. Earthquake Res. Inst. Univ. Tokyo, 57, 83-104, 1982.

Kasahara, J., T. Matsubara, T. Sato, S. Koresawa, and H. Katao, Development of MOOBS/H (magneto-optical ocean bottom seismometer with hydrophone)-1, J. Marine Acoust. Soc. Jpn, 22, 253-267, 1995 (in Japanese with English abstract).

Kasahara, J., T. Matsubara, T. Sato, and K. Mochizuki, Development of high performance digital OBS/H (ocean bottom seismometer and hydrophone) MOOBS-24, J. Marine Acoust. Soc. Jpn, 24, 39-47, 1997 (in Japanese with English abstract).

Kissling, E., W. L. Ellsworth, D. Eberhart-Phillips, and U. Kradolfer, Initial reference models in local earthquake tomography, J. Geophys. Res., 99, 19635-19646, 1994.

Miura, S., S. Kodaira, A. Nakanishi, T. Tsuru, N. Takahashi, N. Hirata, and Y. Kaneda, Structural characteristics controlling the seismicity of southern Japan Trench fore-arc region, revealed by ocean bottom seismographic data, Tectonophysics, 363, 79-102, 2003

Mochizuki, M., T. Watanabe, and T. Kanazawa, Development of ocean bottom seismometer for long-term broadband observation, in Proceedings of the Inter. Symposium on New Images of the Earth's Interior through Long-term Ocean-floor Observations, Kazusa Academia Center, Japan, pp. 77-79, Nov. 6-8, 1997.

Nishino, M., Seismic structure of interplate seismogenic zone off Fukushima in the southern Japan Trench, M. Sc. thesis, Tohoku Univ. pp. 154, 1999 (in Japanese).

Nishizawa, A., T. Kono, A. Hasegawa, T. Hirasawa, T. Kanazawa, and T. Iwasaki, Spatial distribution of earthquakes off Sanriku, northeastern
Japan, in 1989 determined by ocean-bottom and land-based observation, J. Phys. Earth, 119, 37-65, 1990a.

Nishizawa, A., S. Tomita, T. Kanazawa, T. Iwasaki, H. Shimamura, and N. Hirata, Hypocenter distribution off Fukushima, June 1987, determined by an ocean bottom seismographic observation, Zisin, 43, 403-411, 1990 b (in Japanese with English abstract).

Nishizawa, A., T. Kanazawa, T. Iwasaki, and H. Shimamura, Spatial distribution of earthquakes associated with the Pacific plate subduction off northeastern Japan revealed by ocean bottom and land observation, Phys. Earth Planet. Inter., 75, 165-175, 1992.

Obana, K., S. Kodaira, K. Mochizuki, and M. Shinohara, Micro-seismicity around the seaward updip limit of the 1946 Nankai earthquake dislocation area, Geophys. Res. Lett., 28, 2333-2336, 2001.

Reasenberg, P. A. and D. Oppenheimer, FPFIT, FPPLOT and FPPAGE: Fortran computer programs for calculating and displaying earthquake fault-plane soulutions, Open-File Report 85-739, Department of the Interior, United States Geological Survey, 1985.

Seno, T. and D. G. Gonzales, Faulting caused by earthquakes beneath the outer slope of the Japan Trench, J. Phys. Earth, 35, 381-407, 1987.

Seno, T. and Y. Yamanaka, Double seismic zones, deep compressional trench-outer rise events and superplumes, in Subduction Top to Bottom, edited by G. E. Bebout, D. W. Scholl, S. H. Kirby, and J. P. Platt, Geophys. Monogr., 96, pp. 347-355, Am. Geophys. Union, Washington, D. C., 1996

Seno, T., D. Zhao, Y. Kobayashi, and M. Nakamura, Dehydration of serpentinized slab mantle: Seismic evidence from southwest Japan, Earth Planets Space, 53, 861-871, 2001.

Shinohara, M., K. Suyehiro, S. Matsuda, and K. Ozawa, Ocean bottom seismometer using portable digital audio tape recorder, J. Japan Soc. Mar. Surv. Tech., 5, 21-31, 1993 (in Japanese with English abstract).

Shiobara, H., A. Nakanishi, and R. Hino, Specifications of ocean bottom seismometers, edited by J. Segawa and S. Ohta, in Preliminary report of the Hakuho-maru cruise KH-96-1, 35-37, 1996.

Sleep, N. H., The double seismic zone in downgoing slabs and the viscosity of the mesosphere, J. Geophys. Res., 84, 4565-4571, 1979.

Suyehiro, K. and A. Nishizawa, Crustal structure and seismicity beneath the forearc off northern Japan, J. Geophys. Res., 99, 22,311-22,347, 1994.

Suyehiro, K., N. Takahashi, Y. Ariie, Y. Yokoi, R. Hino, M. Shinohara, T. Kanazawa, N. Hirata, H. Tokuyama, and A. Taira, Continental crust, crustal underplating, and low-Q upper mantle beneath an oceanic island arc, Science, 272, 390-392, 1996.

Tsumura, K., Determination of earthquake magnitude from total duration of oscillation, Bull. Earthquake Res. Inst. Univ. Tokyo, 45, 7-18, 1967.

Tsuru, T., J.-O. Park, S. Miura, S. Kodaira, Y. Kido, and T. Hayashi, Alongarc structural variation of the plate boundary at the Japan Trench margin: Implication of interplate coupling, J. Geophys. Res., 107(B12), 2357, doi:10.1029/2001JB001664, 2002.

Umino, N., A. Hasegawa, and A. Takagi, The relationship between seismicity patterns and fracture zones beneath northeastern Japan, Tohoku Geophys. J., 33, 149-162, 1990.

Urabe, T. and N. Hirata, A playback system for long term analogue tape recordings of ocean bottom seismographs, Zisin, 37, 633-645, 1984 (in Japanese with English abstract).

Urabe, T., Seismological regionality of the middle Japan Trench (Fukushima-oki) revealed by ocean bottom seismography, D. Sci. thesis, Univ. of Tokyo, 158 pp, 1987.

Urabe, T. and S. Tsukada, win-A workstation program for processing waveform data from microearthquake networks, Prog. Abst. Seismol. Soc. Jpn., 2, P-41, 1992 (in Japanese).

Yakiwara, H., T. Kakuta, H. Miyamachi, K. Goto, S. Hirano, R. Hino, T. Kanazawa, Y, Kaiho, H. Shiobara, T. Watanabe, M. Mochizuki, H. Nemoto, and H. Shimamura, Seismic activity inferred from ocean bottom seismographic observation around Tokara Channel-north region off Amami Oshima, Nansei Syoto Islands, western Japan, Zisin, 49, 227-239, 1996 (in Japanese with English abstract).

Wessel, P. and W. H. F. Smith, New, improved version of the Generic Mapping Tools released, Eos Trans. AGU, 79, 579, 1998.

Zhao, D., A. Hasegawa, and H. Kanamori, Deep structure of Japan subduction zone as derived from local, regional, and teleseismic events, $J$. Geophys. Res., 99, 22313-22329, 1994.

M. Shinohara (e-mail: mshino@eri.u-tokyo.ac.jp), R. Hino, T. Yoshizawa, M. Nishino, T. Sato, and K. Suyehiro 